\title{
Assessing the origin of Cenozoic intraplate magmatism in Mongolia
}

\author{
M. PAPADOPOULOU*, T. L. BARRY, A. C. RUTSON
}

SGGE, University of Leicester, Leicester, LE1 7RH, UK

(*correspondence: mp589@le.ac.uk, tlb2@le.ac.uk)

In Mongolia, East Asia, intraplate volcanism has occurred intermittently since the Late Cretaceous, to present day. Mesozoic volcanism was widespread throughout the southern and eastern parts of Mongolia. Cenozoic basaltic volcanism produced relatively small volume $\left(<30 \mathrm{~km}^{3}\right)$ [1], diffusely dispersed plateaus that extend through the central parts of the country, from north to south. On the contrary, the Dariganga plateau in the southeast, is a concentration of $>200$ volcanic cones, covering an area $>10,000 \mathrm{~km}^{2}$.

Although several models have tried to explain the Cenozoic magmatism in Mongolia, there is no clear evidence of what causes the volcanic activity. Here, we assess the three mostcommonly invoked models used to explain the Mongolian magmatism. (1) First we will test the hypothesis of the existence of a mantle plume beneath Mongolia using new ArAr age constraints on volcanic rocks from Dariganga, Gobi Altai and the Valley of Lakes. (2) Secondly, topographic and field observations will be used to assess a crustal extension model. (3) Following the idea of lithospheric delamination during the Mesozoic [2, 3] we will assess the possibility of an existing link between the Mesozoic and Cenozoic magmatism using geochemical data and tomographic images of the upper mantle beneath Mongolia.

In the absence of conclusive evidence to support either the plume or the crustal extension model, we explore the implications of a Mesozoic delamination event for the melt genesis of the Cenozoic magmas.

[1] Barry et al. (2003) J. Petr 44(1), 55-91. [2] Windley et al. (2010) Amer. J. Sci. 310, 1250-1293. [3] Sheldrick et al. (2018) Lithos 296-299, 297-315. 